\title{
DEVELOPING GUIDELINES FOR RIVERFRONT DEVELOPMENTS FOR MALAYSIA
}

\author{
AZLINA BINTI MD. YASSIN \\ University Tun Hussein Onn Malaysia
}

\section{SANDY BOND and JOHN McDONAGH \\ Lincoln University}

\begin{abstract}
Rivers and water are important resources for human life, the environment and national development. In Malaysia, the importance of rivers as the focal point of cities was established from the early times of civilisation and will remain so. Population growth, economic growth, urbanisation and increased technology have transformed many Malaysian river systems from water industries into non water industries. Due to these changes, the functions of riverfront areas have also changed and the current pattern of riverfront development in Malaysia now focuses more on mixed-use development and recreation.
\end{abstract}

To date, numbers of riverfront development projects are being developed in Malaysia for recreation, residential and mixed-use. Unfortunately, in most cases, the developments identified are not successful, having cost effects more than their economic value. Example are increases in water pollution indexes and rates of juvenile problems.

The focus of this study was to identify the attributes of riverfront development, in order to develop guidelines for riverfront development for Malaysia. The findings of this study were based on interviews conducted with Government officers, Property developers, and the Waterfront community from three case study areas (qualitative phase), and from questionnaires mailed and e-mailed to property development companies listed under Bursa Malaysia (quantitative phase). The findings identified 18 attributes to be used in assisting developers when undertaking riverfront projects in the future. The attributes identified were then recommended to be used as guidelines of best practices of riverfront development in Malaysia.

Keywords: Waterfront, waterfront development, riverfront development, riverfront development guidelines. 


\section{INTRODUCTION}

Rivers and water are valuable natural resources for human life, the environment and national development. Malaysia has 519 rivers, approximately 57,300 kilometres in length and, among them, 189 function as river basins, 30 of which function as reservoirs to supply the 28 million people living in Malaysia. In fact, water is supplied to more than $95 \%$ of the population 24 hours each day (Weng, 2009).

Moreover, since the beginning of civilisation, rivers have played a major and important role in shaping and influencing the development of the nation and the culture of its people. In fact, in Malaysia, settlements have historically sprung up along river banks, hence, many urban cities in Malaysia such as Kuala Lumpur, Terengganu, Malacca, Kuantan, Kota Bharu, and Kuching were established after waterfront settlements had developed - developed on river edges or in river valleys (Andaya \& Andaya, 2001; Latip, Heath, Shamsuddin, Liew, \& Vallyutham, 2010; Weng, 2005). As a consequence, some of the villages were named after the rivers that ran through them namely, Sungai Rengit, Sungai Mati and Sungai Kapal in Johor (Yassin, Eves \& McDonagh, 2010a).

Rapid development and urbanisation all over the country, especially following earlier civilisation and including waterfront areas, is causing the deterioration of the natural environment such as by flooding, pollution and drought (Weng, 2002, 2009; Weng, Ibrahim, \& Hajar, 2002). These problems disturb economic growth and the activities of life and can result in the loss of property and lives (Abidin, 2004; Malaysian Department of Environment, 2007). Also, not effective governance and inadequate regulations for the control of waterfront developments in this country (Latip et al., 2010; Yassin, Eves, \& McDonagh, 2010b) have led Malaysia to suffer with adverse environmental and social effects.

Therefore, this paper aims to identify attributes which are desirable to be included in the guidelines for riverfront development in Malaysia in the future, from the waterfront development stakeholder's point of view. A sequential exploratory mixedmethod strategy was adopted in this research, a qualitative method followed by a quantitative method. A qualitative method by way of case studies with one-to-one interviews and document reviews was used to investigate the relevant information for regulations and guidelines of riverfront development in Malaysia. Information gathered was then included in a questionnaire, which was then distributed to property development companies in Malaysia. The purpose of the quantitative phase (questionnaire survey) was to confirm statistically the respondents' responses about riverfront development guidelines in an effort to improve riverfront development practices in Malaysia in the future. 


\section{REVIEW OF THE LITERATURE}

\section{Waterfronts and waterfront development}

In general, the waterfront refers to land fronting on to water. The waterfront is a zone of interaction between urban development and the water and a waterfront area is considered to be a unique and irreplaceable resource where it interfaces between land, water, air, sun and productive plants (Wrenn, 1983).

By being an interface between land and water, the waterfront zone is an area endowed with special characteristics. The special features and functions of waterfront areas are presented in Table 1.

\section{Table 1: Special characteristics of a waterfront zone}

\section{Characteristic Descriptions}

Ecological

The waterfront zone is a dynamic area with frequently changing biological, chemical and geological attributes.

The waterfront zone includes highly productive and biologically diverse ecosystems that offer crucial nursery habitats for many marine species.

Economic

The waterfront contributes significantly to human welfare, both directly and indirectly.

The waterfront zone is socially important for global

Social transportation, open access and common property and is a unifying element in the cultures of different peoples within countries.

(Source: Costanza, 1999)

In the development context, Butuner (2006) sees waterfronts as land to be reclaimed from water in order to create an extension of the existing city centres. Breen \& Rigby $(1996,1994)$ considered that a waterfront development may not necessarily need to directly front water but may need only to look as if it is attached to the water. They believe that a property commanding a view of the water can be considered as a waterfront property.

In summary, a waterfront development is best represented as a development directly fronting water for any purpose and the water components can include river deltas, coastal plains, wetlands, beaches and dunes, lagoons and other water features. Also, the boundary where the water and land meet is difficult to determine and depends on jurisdictional limits and the administration of the country. 


\section{Why waterfronts?}

Over recent few decades, waterfront development and redevelopment has evolved and taken on its own identity in areas such as historic preservation and recreation. In particular, the patterns of development are changing by connecting land, water, and air and landscape aesthetics to land development planning. According to Gaffen (2004), the growing focus on restoring urban waterfronts can be attributed to several factors, as follows:

(1) Environmental awareness and smart growth

Local governments are starting to re-examine the importance of smart growth, particularly the minimisation of urban sprawl, a proven culprit in many pollution problems. In order to achieve the objectives of smart growth, developers are required to follow approaches that include the provision of mixed land uses, taking advantage of compact building designs; developing a range of housing opportunities and choices; fashioning walk-able neighbourhoods; preserving open spaces - farmland, natural beauty and critical environmental areas; strengthening and directing development towards the existing communities; making development decisions that are predictable, fair and cost-effective; and encouraging community and stakeholder collaboration in development decisions.

\section{(2) Preservation and adaptive reuse}

Abandoned buildings and vacant spaces along the waterfront cause a decline in property values, as well as creating an environment for criminal activities. Therefore, the preservation and regeneration of older buildings and vacant waterfront areas and neighbourhoods have made some cultural contribution to a city or a country as well as maintaining community identity and encouraging community pride.

\section{(3) Federal assistance}

A stronger focus by government institutions about urban renewal has made possible much waterfront development and waterfront redevelopment. Federal governments can assist waterfront development through management and the provision of sufficient funds.

\section{(4) Tourism industry}

Increased demand by the tourism industry and tourism businesses was a major contributor to waterfront development and redevelopment. Special features of waterfront areas are able to attract visitors and enhance tourism in many countries.

\section{(5) Recreation or fitness}

The special characteristics of waterfront areas offer opportunities for many outdoor activities and recreation for the public. Increased demand from the public for recreational spaces and water based entertainment has encouraged governments to undertake waterfront development and redevelopment. 


\section{Principles for successful waterfront development}

According to Torre (1989), development along the water area should meet human and water body needs. Torre (1989) determined that the success of a waterfront development was only achieved once it can function on all levels and benefit all stakeholders. It is important to take advantage of the amenities and to balance public participation in order to maintain waterfront uses. For this reason, the connections discovered between the water and the public, as well as defining attributes that fundamentally shape the character of waterfront areas, are later incorporated into the waterfront development process and are very important.

In addition, Bertsch (2008) determined that for any use of a waterfront area, a water plan should be developed before the land plan to maintain an economically viable waterfront. Therefore, Bertsch (2008) recommended five principles that must be included while developing plans for waterfront areas and are as follows:

(i) Accessibility - waterfronts should not be isolated or separated from the development, so that the public can access the waterfront easily (convenient means for visitors to access the waterfront area).

(ii) Integrated - integration of the history, culture and existing architecture is recommended for a new waterfront development.

(iii) Sharing benefits - a balance between public benefit and developer profitability must be found. A public-private partnership is essential to realise the inspiration of the design.

(iv) Stakeholder participation - the involvement of all of interested parties is compulsory. Government agencies, developers, community organisations, environmental groups and the public all have a stake in the development of a waterfront property and all must be involved in the process.

(v) Construction phase - breaking down a huge project into several phases and allowing all stakeholders and the general public to see this provides a vision of the future.

Thus, apparently, the harmonies of waterfront development could be achieved through combinations of people, nature and technology (Mann, 1973).

\section{Principles for sustainable waterfront development}

Waterfronts are one of the most valuable resources for a country - being limited, precious and non-renewable assets. To secure long-term growth of the resource, it is important for waterfront areas to be used strategically to maintain their economic 
value and enhance their specific features or image (Bruttomesso, 2006). For this reason, Bruttomesso (2006) recommended 10 principles in order to secure in achieving waterfront redevelopment projects as are presented in Table 2.

\section{Table 2: Principles for sustainable waterfront development}

\begin{tabular}{|c|c|}
\hline $\begin{array}{l}\text { Ten principles for a } \\
\text { sustainable waterfront } \\
\text { development }\end{array}$ & $\begin{array}{l}\text { Secure the quality of water and the environment. } \\
\text { Waterfronts are part of the existing urban fabric. } \\
\text { The historic identity gives character. } \\
\text { Mixed-use is a priority. } \\
\text { Public access is a prerequisite. } \\
\text { Planning in public-private partnerships speeds the process. } \\
\text { Public participation is an element of sustainability. } \\
\text { Waterfronts are long term projects. } \\
\text { Revitalisation is an ongoing process. } \\
\text { Waterfronts profit from international networking. }\end{array}$ \\
\hline
\end{tabular}

(Source: Bruttomesso, 2006)

\section{RESEARCH METHODS}

A mixed methods research strategy - sequential exploratory mixed method strategy, consisting of a qualitative approach followed by a quantitative approach was employed in this study. The qualitative phase in this study was a case study, which was followed by a survey questionnaire in the second phase (quantitative approach). In this study, three case study areas were selected namely: Kuching Waterfront in Sarawak, Malacca Waterfront in Malacca and Glenmarie Cove Riverfront in Selangor. For the quantitative approach, the sample data comprised of property development companies listed at Bursa Malaysia during 2009.

The strengths of both qualitative (identification of new considerations) and quantitative methods (confirmation of statistical significance of newly identified considerations) were combined in order to provide more robust and comprehensive results. The use of multiple methods within a single study offered wide perspectives and more extensive results through the combination of a variety of data sources (Creswell, Clark, Gutmann, \& Hanson, 2003; Morse, 2003; Tashakkori \& Teddlie, 2003).

\section{RESULTS AND DISCUSSION}

This section presents results derived from the exploratory analysis and the statistical analysis. 


\section{Qualitative results}

\section{Response rate}

Interviews were sufficiently well answered to allow a response rate of $100 \%$ to be obtained. A total of 25 face-to-face interviews were conducted within the 10 weeks from the $10^{\text {th }}$ of May to the $20^{\text {th }}$ of July 2009. Input was obtained from three different sources: (i) Federal, State and Local Governments, (ii) Private developers, and (iii) waterfront community. Figure 1 present the diversification of the interviewees who participated in the interviews.

\section{Figure 1: Diversification of the respondents}

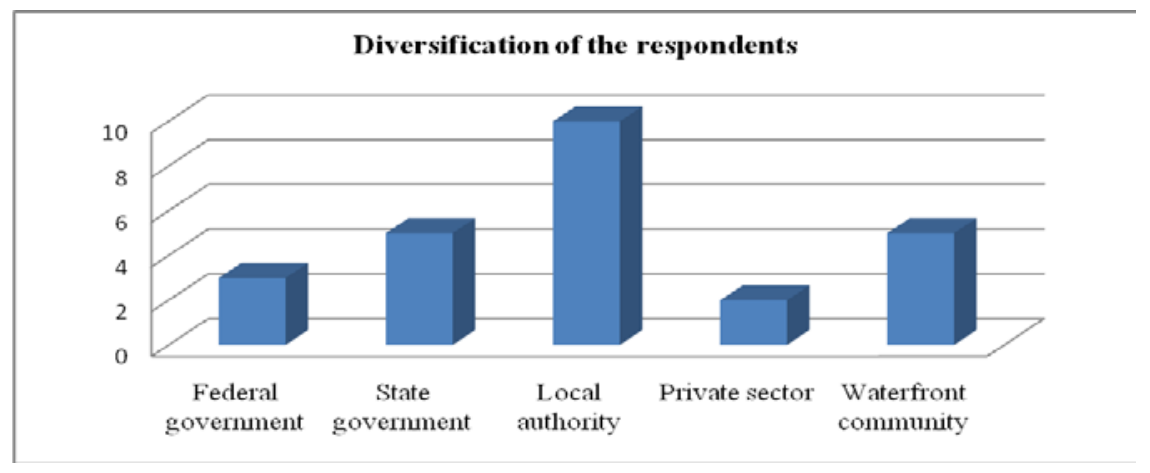

Guidelines for riverfront development

Q: $\quad$ Guidelines for riverfront development is designed mainly to control development in front of water areas, particularly close to river areas. Are you aware about this guideline?

From the interviews, it appears that the majority of respondents (84\%) are aware of the guidelines for riverfront development while the rest (26\%) are not familiar with these.

The $84 \%$ of respondents who are aware and familiar with the guidelines were further asked about the sufficiency of the guidelines for controlling waterfront development in Malaysia.

Q: $\quad$ Is this guideline considered effective towards successful riverfront development? 
From the interviews, it appears that only $14.3 \%$ thought that guidelines for riverfront development were sufficient to control waterfront development in Malaysia and the majority of them (about 85.7\%) thought that the guidelines were not sufficient to control waterfront development.

The 18 respondents (85.7\%) who indicated that the guidelines for riverfront development are insufficient for controlling waterfront development in Malaysia were then asked for the reasons behind that view. More than half (56\%) of the respondents who indicated that the guidelines for riverfront development are not sufficient for controlling riverfront development in Malaysia, identified that they are insufficient to control environmental issues as a primary reason for their being ineffective. Thirtytwo percent of respondents identified that guidelines for riverfront development are not effective due to an inability to encourage sustainable riverfront development. A few respondents (16\%) indicated that the guidelines were difficult to implement due to not including comprehensive explanations.

\section{Recommendations for best practice riverfront development in Malaysia}

At the end of the interview sessions, all 25 respondents were asked for their opinions on statements that should be included in guidelines for the achieving of successful riverfront developments in Malaysia. Respondents' opinions or suggestions took into consideration several negative effects and working to overcome or, at least, reduce the problem. All 25 respondents were asked an interview question as follows:

Q: $\quad$ Considering of all barriers and limitations, what is your recommendation relating to a new guideline for waterfront development in Malaysia incorporating economical, environmental and social factors?

All 25 respondents gave useful feedback that resulted in eighteen statements being recommended. From the eighteen recommendations, $44 \%$ of respondents thought that all riverfront development projects should require compulsory approval for Environmental Impact Assessment (EIA). Moreover, 56\% of respondents thought that new guidelines for riverfront development in Malaysia should emphasise on river reserves beautification and continuously rehabilitate river itself. Respondents also thought that the guidelines for riverfront development should include provision for sufficient public facilities and amenities such as pedestrian paths, toilets, landscaping and recreation areas which accounted for 52\%. Respondents' suggestions on statements that should be including in new guidelines for riverfront developments in Malaysia are summarised and presented in Table 3. 
Table 3: Statements for riverfront development guidelines

\begin{tabular}{cccc}
\hline No. & Statement & No. & Statement \\
\hline 1. & Environmental Impact Assessment & 10. & Continuous river rehabilitation.
\end{tabular}
(EIA) is compulsory.

2. Environment protection and awareness.

11. River reserve beautification.

3. Maintenance and rehabilitation costs

12. Upgrading and maintaining the are shared between stakeholders. sewage system.

4. Use environmentally friendly materials in construction.

5. Provide flood mitigation (e.g. by planting more trees).

13. Restrict type of development.

14. Integrate both modern and heritage aspects into development.

6. Protection of natural resources (water and environment).

15. Encourage economic activities

7. Provision of sufficient public facilities and amenities (such as pedestrian paths, landscaping, access ways, recreation areas, etc.)

8. Personal security is maintained by means of policing, surveillance cameras, etc.

9. Upgrading and maintaining established settlements along the waterfront area.

16. Sharing waterfront benefits (such as views, financial rewards, etc.) among stakeholders (e.g. community, government, developer).

17. Continuously educate public about environmental concerns.

18. Provide regulations and policies that mitigate market speculation for waterfront properties.

\section{QUANTITATIVE RESULTS}

\section{Response rate}

In the second phase of data collection in this research, the sample data comprises property development companies listed under Bursa Malaysia during 2009. 91 property development companies were listed in 2009 (Bursa Malaysia, 2009). 
Of the 91 questionnaires mailed and e-mailed to the respondents, 61 were returned within three months of the response period (survey was conducted between April and July, 2010). This resulted in a total of $67 \%$ useable response rate.

\section{Profile of property development companies}

Information of the property development companies who were respondents to the survey questionnaire was supplied as background information in order to provide more detail about the respondents. The profile of property development companies in Malaysia are presented in Table 4.

\section{Table 4: Profile of respondents}

\begin{tabular}{|c|c|c|c|c|}
\hline \multirow{4}{*}{\begin{tabular}{l}
\multicolumn{1}{c}{ Variables } \\
Location of \\
operations
\end{tabular}} & \multicolumn{2}{|r|}{ Details } & $\mathbf{n}=\mathbf{6 1}$ & Percent (\%) \\
\hline & \multicolumn{2}{|c|}{ National (within Malaysia) } & 49 & 80.3 \\
\hline & \multicolumn{2}{|c|}{ International (outside Malaysia) } & 0 & 0 \\
\hline & \multicolumn{2}{|c|}{ Both national and international } & 12 & 19.7 \\
\hline \multirow{5}{*}{$\begin{array}{l}\text { Year of } \\
\text { operating }\end{array}$} & \multicolumn{2}{|l|}{ Below 1 year } & 0 & 0 \\
\hline & \multicolumn{2}{|l|}{2 - 5 years } & 0 & 0 \\
\hline & \multicolumn{2}{|c|}{$6-10$ years } & 4 & 6.6 \\
\hline & \multicolumn{2}{|c|}{ Over 10 years } & 57 & 93.4 \\
\hline & \multicolumn{2}{|c|}{ Not sure } & 0 & 0 \\
\hline \multirow{5}{*}{$\begin{array}{l}\text { Number of } \\
\text { employees }\end{array}$} & \multicolumn{2}{|c|}{$0-10$ people } & 0 & 0 \\
\hline & \multicolumn{2}{|c|}{11 - 50 people } & 6 & 9.8 \\
\hline & \multicolumn{2}{|c|}{$51-100$ people } & 10 & 16.4 \\
\hline & \multicolumn{2}{|c|}{ Over 100 people } & 42 & 68.9 \\
\hline & \multicolumn{2}{|c|}{ Do not know / Not sure } & 3 & 4.9 \\
\hline \multirow{7}{*}{$\begin{array}{l}\text { Type of } \\
\text { development } \\
\text { projects }\end{array}$} & Residential: & Yes & 61 & 100 \\
\hline & Commercial & Yes & 53 & 86.9 \\
\hline & & No & 8 & 13.1 \\
\hline & \multirow[t]{2}{*}{ Industrial: } & Yes & 25 & 41 \\
\hline & & No & 36 & 59 \\
\hline & \multirow[t]{2}{*}{ Others: } & Yes & 7 & 11.5 \\
\hline & & No & 54 & 88.5 \\
\hline
\end{tabular}

From the results, it appears that the range of the respondents represented in the sample were similar: in that they were property development companies that had been actively practising property development for many years and were listed in Bursa Malaysia. 


\section{Recommendations on the statements for riverfront development guidelines}

The responses indicated that the majority of respondents agreed with all of the statements suggested for future guidelines for riverfront development in Malaysia, with an average mean score of 4.08 . The results showed that each statement suggested indicated mean scores close to 4.0, indicating that respondents agreed the statement should be included in the future riverfront development guidelines in Malaysia. Table 5 summarises the responses.

Table 5: Statement of riverfront development guidelines

\begin{tabular}{lcc}
\hline \multicolumn{1}{c}{ Statement } & Mean scores & Ranking \\
\hline River reserve beautification. & 4.39 & 1 \\
Participation among stakeholders should be compulsory at & 4.36 & 2 \\
every stage of the development. & 4.33 & 3 \\
Environmental Impact Assessment (EIA) is compulsory. & 4.31 & 4 \\
Sharing waterfront benefits (such as view, financial rewards, & & \\
etc.) among stakeholders (e.g. community, government, & 4.28 & 5 \\
developer). & 4.26 & 6 \\
Continuous river rehabilitation. & 4.21 & 7 \\
Upgrading and maintaining sewage system. & 4.20 & 8 \\
Maintenance \& rehabilitation costs are shared between & 4.18 & 9 \\
stakeholders. & 4.13 & 10 \\
Provides flood mitigation (e.g. by planting more trees). & 4.07 & 11 \\
Should use environmentally friendly materials in construction. & 3.93 & 12 \\
Encourage economic activities. & & \\
Protection of natural resources (water and environment). & 3.92 & 13 \\
Provision of sufficient public facilities and amenities (such as & & \\
pedestrian, landscaping, access ways, recreation areas, etc.). & 3.90 & 14 \\
Personal security is maintained by means of policing, & 3.89 & 15 \\
surveillance cameras, etc. & 3.85 & 16 \\
Integrate both modern and heritage aspects into development. & 3.64 & 17 \\
Restrict type of development. & & \\
Continuously educate public about environmental concerns. & 3.54 & 18 \\
Upgrading and maintaining established settlements along the & & \\
waterfront area. & & \\
Mitigate property speculation. & & \\
& & \\
Average mean score = 4.08 & &
\end{tabular}

$*$ Scale: from strongly disagree $=1$ to strongly agree $=5$

\section{Exploratory factor analysis (EFA) results}

A principal component factor analysis specifying six factors that included all variables for waterfront development guidelines was attempted with a VARIMAX normalised 
rotation to highlight a simple structure amongst the six factors identified. ${ }^{2}$ Table 6 below summarises the results of the exploratory factor analysis. The six factors extracted by factor analysis explained $66.26 \%$ of the variation in the data.

All factor loadings ranged from 0.548 to 0.821 . Each factor was named according to the salient themes among the items (Hair et al., 2006). The final factors were identified as Environment (Factor 1), Waterfront benefits (Factor 2), Mitigation (Factor 3), Beautification (Factor 4), Security (Factor 5), and Type of development (Factor 6). Hair et al. (2006) determined items with higher loadings had a greater influence on the name selected to represent the factor and the name assigned to the factor should accurately reflect the items loaded on that factor.

Factor 1 was named 'Environment', and was strongly correlated with variables associated with environmental matters. The variables included in Factor 1 were listed as presented in Table 6 such as 'Environment Impact Assessment (EIA) is compulsory', 'maintenance \& rehabilitation costs are shared between stakeholders' 'upgrading and maintaining established settlement along the waterfront areas'.

Maintaining the green corridor along the water body will provide an important amenity for residents and visitors. By conserving the waterfront and waterfront environment, it would also preserve for future generations. According to Bertsch (2008), taking into consideration several principles such as integration of the history, culture and existing architecture and involvement of multitudes of interested parties, are compulsory while developing waterfront development for maintaining an economically viable waterfront. Moreover, environmental approval from various agencies is required and considered as a rule of thumb for successful waterfront development (Torre, 1989) and subsequently achieving sustainable waterfront development (Bruttomesso, 2006).

The second factor was named 'Waterfront benefits'. This factor included several factors such as 'sharing waterfront benefits such as view, financial rewards, etc. among stakeholders (e.g. community, government, developer)' and 'encouraging economic activity'. Sharing waterfront benefits such as waterfront views is important among waterfront stakeholders such as government, community and developer. As determined by Bertsch (2008), the successful of waterfront development could only be achieved by balancing between public benefit and developer profitability.

\footnotetext{
${ }^{2}$ In this research, an orthogonal rotation (VARIMAX) was conducted. The Latent root criterion and Scree Test Criterion, which state that only factors with Eigenvalues greater than one should be used, was also considered in the choice of the number of factors to include (Hair, Black, Babin, Anderson, \& Tatham, 2006).
} 
Despite of sharing waterfront benefits among stakeholders, participation of all stakeholders is compulsory in each stage of waterfront development. The emerging role of government in a development project (acting as a facilitator and/or a provider) is common and, the involvement of public community in the planning and implementation of local initiatives is required. Choguill (1996) suggests that local participation is important particularly to solve local problems including resource management and development. Thus, though the use of locally generated solutions, the active involvement of residents in their own affairs and a facilitating government, would be expected as a sound basis for successful of waterfront development in Malaysia. Bruttomesso (2006) believed that the public participation is an element to secure long-term of the resources as well as waterfront areas.

Factor 3 was named 'Mitigation' and emphasised on public awareness towards environment concerns. Two variables were loaded in Factor 3, namely 'mitigate property speculation' and 'continuously educate the public about environmental concerns'. According to Tong \& Chen (2002), one of the greatest causes of water quality problems are derived from built up urban land uses as a result of the increasing intensity of human activities. In addition, land use and land cover changes can play a pivotal role in environmental changes and contribute to global change (Meyer \& Turner1991). Therefore, continuously educating people about environmental concerns by providing them updated information about waterfront development projects is important to help maintain the quality of the environment. In addition, including public consideration at every stages of waterfront development process would increase public awareness and responsibility towards waterfront environment (self-belonging on to waterfront project) (Torre, 1989).

Factor 4 was named 'Beautification', which was related to protecting natural resources close to waterfront development areas. This factor included two variables, namely 'river reserve beautification' and 'protecting of natural resources, for example water and environment'. By preserving the natural resources, this helps maintain the economic value of the river, provides a pleasant environment for water sports and picnic activities and improve water quality. According to Torre (1989), maintaining original values in the waterfront and areas surrounding them is important for a successful waterfront development. Moreover, Bruttomesso (2006) determined that continuously beautification work of waterfront areas, protecting of river resources and secure the quality of water and the environment are important elements for sustainable waterfront development. Therefore, including the 'Beautification' factor in the guidelines for riverfront development in Malaysia is important to maintain economic value of waterfront areas.

Factor 5 was named 'Security'. Two variables loaded within this factor were 'personal security is maintained by means of policing, surveillance cameras, etc.' and 'should use environmentally friendly materials in construction'. Despite recreation space and 
availability of goods and services, security was also identified as an important factor that aids good development. Security can include security serviced and measure and fully fenced of property (Logan, 2001). Although historical records show that there are very few vehicle accidents involving open waterways, there is a perception that unfenced bodies of water may pose a safety threat to children. Moreover Bicknell \& Gan (1997) identified that an open waterways can collect debris that imparts an extremely untidy look to the area. Thus, a combination of security factors is appropriate for new guidelines for riverfront development for Malaysia.

Factor 6 posed a challenge as most variables with high loadings were categorised with other factors. In the end, this factor was named 'Type of development' as this was the only variable that remained. According to Yunus, Nakagoshi, \& Ibrahim (2003), types of development (land-uses) are significantly correlated to water quality. For example, built up areas along the Penang river indicate a strong negative relationship with water quality ( $r=-0.911$ in 2000), as compared to forested areas ( $r=0.861$ in 2000). These findings confirm that one of the greatest causes of water quality problems are derived from land-use type as a result of the increasing intensity of human activity. Tong \& Chen (2002) also identified that runoff from different types of land use may be enriched with different kinds of contaminants. Moreover, Bruttomesso (2006) determined that prioritised to mixed-use development type is necessary for achieving sustainable waterfront development. Thus, knowing the land-water relationship is an important consideration for planners and decision makers in designing the plans for water quality matters and for the developer in developing a waterfront project. 
Table 6: Factor analysis results: principal component extraction

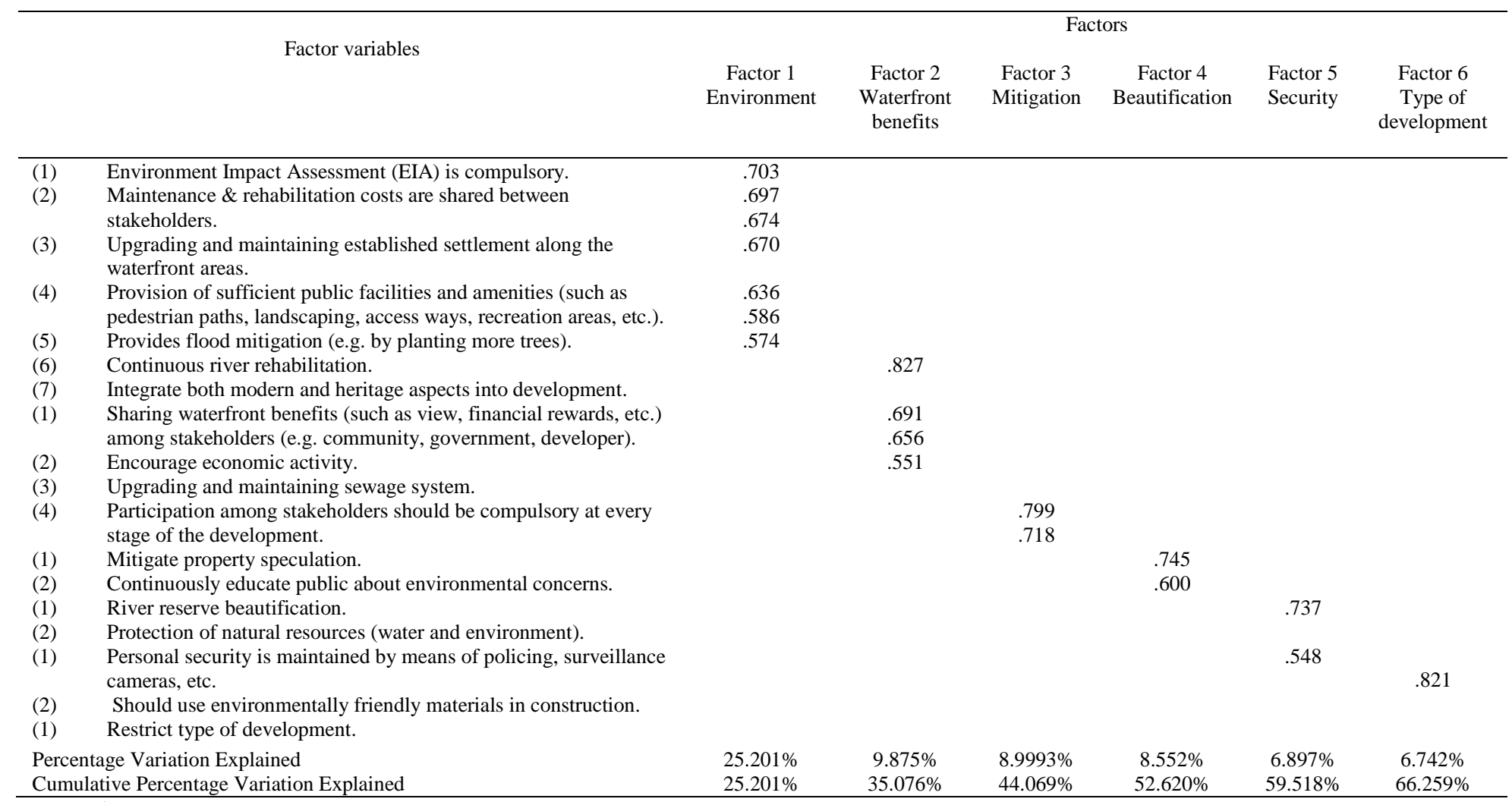

*Factor loadings in the range of \pm .30 to \pm 040 are considered to meet the minimal level for interpretation of structure. Loadings \pm .50 or greater are considered practically significant, and loadings exceeding \pm .70 are indicative of well defined structure (Hari et al, 2006). 


\section{CONCLUSION}

This paper attempts to identify statements that could be important for guidelines for riverfront development and then to recommend riverfront development guidelines for best practice riverfront development in Malaysia. Based on the qualitative and quantitative results, all the variables were shown to be significant and thus were important to be included in the riverfront guidelines for Malaysia. The government needs to revise the existing regulations for controlling riverfront development in Malaysia, by adopting the recommended statements for guidelines for riverfront development. In this regard, they should recognise the importance of environmental concerns and sharing costs and benefits among the stakeholders involved during the riverfront development process. This would help the government facilitate and control riverfront development in Malaysia. The government and specifically the policy makers should strictly enforce the guidelines recommended for best practice for riverfront development in Malaysia in order to achieve successful riverfront outcomes similar to other countries.

\section{REFERENCES}

Abidin, R. Z. R. Z. (2004). Water resources management in Malaysia: The way forward. Paper presented at the Asia Water 2004 (30 March - 02 April 2004).

Andaya, B. W., \& Andaya, L. Y. (2001). A history of Malaysia (Second ed.). Hampshire, Britain: Palsgrave .

Bertsch, H. (2008). The key elements to successful waterfront design. Real Estate Weekly, 54.39.

Bicknell, K. B., \& Gan, C. (1997). The value of waterway enhancement in Christchurch: A preliminary analysis (Department of Economics and Marketing discussion paper). Canterbury, New Zealand: Department of Economics and Marketing.

Breen, A., \& Rigby, D. (1996). The new waterfront: A worldwide urban success story. New York: McGraw-Hill.

Breen, A., \& Rigby, D. (Eds.). (1994). Waterfronts: Cities reclaim their edge. United State: McGraw-Hill, Inc.

Bruttomesso, R. (2006). Waterfront development: A strategic choice for cities on water. Paper presented at the Waterfront Development Forum: China Maritime (02 March 2006), Hong Kong. 
Bursa Malaysia. (2009). Kuala Lumpur, Malaysia: Bursa Malaysia.

Butuner, B. (2006). Waterfront Revitalisation as a Challengeing Urban Issue. Paper presented at the 42nd ISoCaRP Congress.

Choguill, C. L. (1996). Towards sustainability of human settlements. Habitat International, 20(3), v-viii.

Cohen, J. W. (1988). Statistical power analysis for the behavioral sciences (2 ed.). New Jersey: Lawrence Erlbaum Associates.

Concise Oxford English Dictionary (Ed.). (2009). (11 ed.). Oxford: Oxford University Press.

Costanza, R. (1999). The ecological, economic, and social importance of the oceans. Ecological Economics, 31, 199-213.

Creswell, J. W., Clark, V. L. P., Gutmann, M. L., \& Hanson, W. E. (2003). Advanced mixed-methods research designs. In A. Tashakorri \& C. Teddlie (Eds.), Mixed methods in social \& behavioral research (pp. 209-240). Thousand Oaks, California: Sage Publications, Inc.

Dong, L. (2004). Waterfront development : A case study of Dalian, China. Unpublished master thesis, University of Waterloo, Canada.

Gaffen, Y. G. (2004). Cities riding waves of success with well planned waterfront restoration. Public Management, 86(10).

Hair, J. F., Black, B., Babin, B., Anderson, R. E., \& Tatham, R. L. (2006). Multivariate Data Analysis (6th ed.): Prentice Hall.

Hoyle, B. (2002). Urban waterfront revitalisation in developing countries: The example of Zanzibar's Stone Town. The Geographical Journal, 168(2), 141-162.

Hussein, H. (2006). Urban recreational riverfronts: Successful revitalisation elements. Journal of Design and the Built Environment, 2 (1).

Kitchin, R., \& Tate, N. J. (2000). Conducting research in human geography: Theory, methodology and practice. Harlow: Prentice Hall.

Latip, N. S. A., Heath, T., Shamsuddin, S., Liew, M. S., \& Vallyutham, K. (2010). The contextual integration and sustainable development of Kuala Lumpur's city centre waterfront: An evaluation of the policies, law and guidelines. Paper presented at the 
The World, Engineering, Science and Technology Congress (ESTCON 2010) (15-17 June 2010), Kuala Lumpur Convention Centre, Malaysia.

Logan, J. R. (2001). The New Ethnic Enclaves in America's Suburbs. Albany, New York: Lewis Mumford Center.

Malaysian Department of Drainage and Irrigation. (2009). Manual and guidelines for water management. Kuala Lumpur, Malaysia: Ministry of Natural Resource and Environment.

Malaysian Department of Environment. (2007). Environmental Quality Report, 2007. Kuala Lumpur, Malaysia: Department of Environment, Ministry of Natural Resources and Environment.

Mann, R. (Ed.). (1973). Rivers in the city. Newton Abbot: David \& Charles.

Meyer, W. B., \& B.L.Turner. (1991). Changes in land use and land cover: A global perspective. Cambridge: Cambridge University Press.

Morse, J. M. (2003). Principles of mixed-method and multi-method research design. In A. Tashakorri \& C. Teddlie (Eds.), Handbook of mixed method in social and behavioral research (pp. 189-207). Thousand Oaks, California: Sage Publication, Inc.

Murray, G. (2003). A Room with a Water View. Beijing Review, 46(19), 26.

Newman, I., \& McNeil, K. (1998). Conducting survey research in the social sciences. Lanham, Maryland: University Press of America.

Ryckbost, P. (2005). Redeveloping urban waterfront property. USA: University of Michigan.

Sapsford, R., \& Jupp, V. (2006). Data collection and analysis. London: SAGE Publications.

Sekaran, U. (2003). Research methods for business: A skill building approach (4th edition ed.). New York, NY: John Wiley \& Sons.

Sweet, S. A., \& Grace-Martin, K. (2008). Data analysis with SPSS: A first course in applied statistics (3 ed.). USA: Pearson Education, Inc.

Tashakkori, A., \& Teddlie, C. (2003). Mixed methods in social and behavioral research. California: SAGE Publications Incorporated. 
Tong, S. T. Y., \& Chen, W. (2002). Modeling the relationship between land use and surface water quality. Journal of Environmental Management, 66, 377-393.

Torre, L. A. (1989). Waterfront development. New York: Van Nostrand Reinhold.

Tunbridge, J., \& Ashworth, G. (1992). Leisure resource development in cityport revitalisation: The tourist-historic dimension. In B. Hoyle \& D. Pinder (Eds.), European port cities in transition (pp. 177-199). London: Belhaven Press.

Wagner, W. E. (2010). Using SPSS for social statistics and research methods (2 ed.). Thousand Oaks, California: Pine Forge Press.

Watson, J. S. (1986). Ross's landing : A river edge park opportunity. Paper presented at the 2nd International Conference on Making Cities Liable.

Weng, C. N. (2002). Sustainable management of rivers in Malaysia: Involving all stakeholders. Paper presented at the Regional Symposium on Environment and Natural Resources (10-11 April 2002).

Weng, C. N. (2005). Sustainable management of rivers in Malaysia - Involving all stakeholders. International Journal River Basin Management, 3(3), 147-162.

Weng, C. N. (2009). Issue and challenges in water governance in Malaysia. Environmental Health Science Engineering, 6(3), 143-152.

Weng, C. N., Ibrahim, A. L., \& Hajar, A. R. (2002). The role of Non-Governmental Organisations in water resources management in Malaysia. Paper presented at the Regional Symposium on Environment and Natural Resources (10-11 April 2002), Hotel Renaissance Kuala Lumpur, Malaysia.

Wrenn, D. M. (1983). Urban waterfront development. Washington, D.C.: The Urban Land Institute.

Yassin, A. M., Eves, C., \& McDonagh, J. (2010a). An evolution of waterfront development in Malaysia. Paper presented at the $16^{\text {th }}$ Pacific Rim Real Estate Society Conference (24-27 January 2010), Intercontinental Hotel, Wellington, New Zealand.

Yassin, A. M., Eves, C., \& McDonagh, J. (2010b). Waterfront development in Malaysia: Do we have sustainable governance? . Paper presented at the $\mathrm{PhD}$. Colloqium Program for $16^{\text {th }}$ Pacific Rim Real Estate Society Conference (24-27 January 2010) Intercontinental Hotel, Wellington, New Zealand. 
Yunus, A. J. M., Nakagoshi, N., \& Ibrahim, A. L. (2003). Application of GIS and Remote Sensing for measuring and evaluating land-use change and its impact on water quality in the Penang River Watershed. Ecol. Civil Eng., 6(1), 97-110.

Zhang, L. (2002). An evaluation an urban riverfront park, Riverfront Park, Spokane, Washington- Experience and lessons for designer. Unpublished master thesis, Washington State University, United States.

\section{Email contact: azlina@uthm.edu.my}

